\title{
Bacterial production in the Delaware Bay estuary estimated from thymidine and leucine incorporation rates
}

\author{
David L. Kirchman, Matthew P. Hoch \\ College of Marine Studies, University of Delaware, Lewes, Delaware 19958, USA
}

\begin{abstract}
The thymidine and leucine methods were examined and used to estimate bacterial production in the Delaware Estuary. During growth experiments that minimized grazing on bacteria, conversion factors for both thymidine and leucine were initially high and then rapidly decreased to values lower than commonly-used factors $\left(2.0 \times 10^{18} \mathrm{cells} \mathrm{mol}^{-1}\right.$ for thymidine). The low thymidine conversion factors may have been due to $\left[{ }^{3} \mathrm{H}\right]$ thymidine incorporation into protein, which was $72 \%$ of total incorporation in untreated samples from the estuary. Addition of glucose reduced the leucine conversion factor from 7.4 to $3.6 \times 10^{16} \mathrm{cells} \mathrm{mol}^{-1}$ and the thymidine conversion factor from 1.53 to $0.68 \times 10^{18}$ cells $\mathrm{mol}^{-1}$. Ammonium additions had no effect. The thymidine and leucine approaches gave similar estimates of bacterial production in the Delaware Bay $\left(20\right.$ to $\left.70 \times 10^{6} \mathrm{cells}^{-1} \mathrm{~h}^{-1}\right)$. Both methods confirmed that bacterial production was highest at about 40 to $50 \mathrm{~km}$ upstream of the mouth, which coincides with the peak in primary production. Bacterial production was about $30 \%$ of primary production in most regions of the estuary, but increased to over $100 \%$ in the turbidity maximum where primary production was low. Bacterial production in the Delaware Estuary is apparently controlled by phytoplankton production in spite of large allochthonous sources of dissolved organic matter.
\end{abstract}

\section{INTRODUCTION}

Estimates of bacterial production have been essential for evaluating the importance of heterotrophic bacteria in consuming primary production and in providing material and energy for higher trophic levels in pelagic ecosystems. Several independent estimates have shown that bacteria consume a large fraction (as high as $60 \%$ ) of primary production (see reviews by Azam et al. 1983, Ducklow 1983). Microbial ecologists are now attempting to separate real from artifactual variation in estimates of bacterial production. Consideration of both methodological and ecological questions simultaneously is likely to be the most productive approach for understanding the controls of bacterial growth and the roles of these microorganisms in pelagic systems.

The most common procedure for estimating bacterial production in aquatic systems is the $\left[{ }^{3} \mathrm{H}\right]$ thymidine method (Fuhrman \& Azam 1982, Parsons et al. 1984). Although the thymidine method has proven to be very useful, several problems have arisen, including isotope dilution caused by biosynthesis of unlabeled precursors (Fuhrman \& Azam 1982) and non-specific incorpora- tion of ${ }^{3} \mathrm{H}$-radioactivity, e.g. into protein (McDonough et al. 1986, Hollibaugh 1988). Because of these problems, Kirchman et al. (1982) suggested a 'black-box' approach to estimate a factor that empirically relates $\left[{ }^{3} \mathrm{H}\right]$ thymidine incorporation rates to bacterial production rates, i.e. the conversion factor.

The Kirchman et al. (1982) approach has been criticized because the resulting conversion factors are often very high, sometimes higher than ecologically possible (e.g. Hobbie \& Cole 1984). Scavia \& Laird (1987) argued that their high conversion factors were ecologically valid and resulted in estimates of bacterial production that balanced independently measured rates of grazing on bacteria and that could be reconciled with rates of primary production. However, other high conversion factors (e.g. some of those of Kirchman et al. 1982) remain unexplained. Determining the correct conversion factor is essential for obtaining accurate estimates of bacterial production.

Kirchman et al. $(1985,1986)$ suggested that $\left[{ }^{3} \mathrm{H}\right]$ leucine incorporation may prove to be a useful measure of bacterial production. The leucine method has not been used extensively with samples from 
natural environments. Kirchman et al. (1986) did show that leucine incorporation followed increases in bacterial abundance and protein in experiments that minimized grazing on bacteria. McDonough et al. (1986) found that $\left[{ }^{3} \mathrm{H}\right]$ leucine incorporation covaried with $\left[{ }^{3} \mathrm{H}\right]$ thymidine incorporation into protein, but not with $\left[{ }^{3} \mathrm{H}\right]$ thymidine incorporation into DNA in depth profiles of a lake with an anoxic hypolimnion. The leucine method could provide an independent check of the thymidine method, but more comparisons of the 2 methods are obviously needed.

We have been measuring bacterial production in the Delaware Estuary as part of a study to examine the role of heterotrophic bacteria in the nitrogen and phosphorus cycles. Coffin \& Sharp (1987) estimated that bacterial production was approximately $23 \%$ of phytoplankton production in the Delaware Bay. To measure bacterial production, Coffin \& Sharp (1987) inhibited grazers of bacteria with cycloheximide and measured the resulting increase in bacterial numbers. Because of uncertainties about the effectiveness of cycloheximide (Taylor \& Pace 1987), we have been using rates of thymidine and leucine incorporation to estimate bacterial production in the Delaware Bay. The purposes of this paper are: (1) to investigate the applicability of the thymidine and leucine techniques in Delaware Bay, and (2) to use these 2 methods to obtain a better qualitative and quantitative picture of bacterial production in the Delaware during the spring phytoplankton bloom.

\section{MATERIALS AND METHODS}

Sampling sites. Water samples were collected from the Delaware Bay, USA, from the RV 'Cape Henlopen'. Sample sites were along the middle axis of the bay and will be referred to by their distance from the mouth (Sharp et al. 1986). All experiments were with surface samples collected with 101 Niskin bottles. Chlorophyll concentrations were measured fluorometrically in acetone extracts (Sharp et al. 1982). Primary amine concentrations were measured by the o-phthalaldehyde method using glycine as the standard (Parsons et al. 1984). Bacterial abundance was measured with acridine orange and epifluorescence microscopy (Hobbie et al. 1977). Primary production was estimated from ${ }^{14} \mathrm{CO}_{2}$ uptake measured over $24 \mathrm{~h}$ in a deck incubator (Pennock \& Sharp 1986). Incubations used 6 light levels obtained with neutral density screens. Areal primary production rates $\left(\mathrm{g} \mathrm{C} \mathrm{m}^{-2} \mathrm{~d}^{-1}\right)$ were estimated from the ${ }^{14} \mathrm{CO}_{2}$ uptake data and photosynthetically available radiation as measured by a QSR250 integrating quantum meter. The volumetric rates of primary production reported here are the highest rates of ${ }^{14} \mathrm{CO}_{2}$ fixation under optimal light conditions for a given location in the estuary.

Incorporation of $\left[{ }^{3} \mathrm{H}\right]$ thymidine and $\left[{ }^{3} \mathrm{H}\right]$ leucine. Incorporation of $\left[{ }^{3} \mathrm{H}\right.$-methyl]thymidine was measured by standard procedures (Fuhrman \& Azam 1982). The final concentration added was $5 \mathrm{n} M$ and the specific activity of added $\left[{ }^{3} \mathrm{H}\right.$ ]thymidine was $>70 \mu \mathrm{Ci} \mathrm{nmol}{ }^{-1}$. Triplicate $10 \mathrm{ml}$ subsamples were taken at every station. In order to determine if $5 \mathrm{nM}$ additions were adequate, isotope dilution experiments were performed (Moriarty \& Pollard 1981). Along with $\left[{ }^{3} \mathrm{H}\right]$ thymidine, various concentrations of nonradioactive thymidine, ranging in final concentration from 5 to $30 \mathrm{nM}$, were added and incorporation of radioactivity was measured. The data were analyzed by nonlinear regression techniques to calculate the maximum incorporation rate $\left(I_{\max }\right)$ (Kirchman et al. 1986).

To determine the proportion of $\left[{ }^{3} \mathrm{H}\right]$ thymidine incorporation into protein, incorporation into the cold and hot TCA insoluble material was compared. The hot TCA extraction consisted of heating samples to $85^{\circ} \mathrm{C}$ for $15 \mathrm{~min}$. The proportion of $\left[{ }^{3} \mathrm{H}\right]$ thymidine incorporation into protein was estimated from the radioactivity retained on the filter after the hot TCA extraction compared with the radioactivity retained after the cold TCA extraction.

Incorporation of $\left[{ }^{3} \mathrm{H}\right]$ leucine was measured by adding $1 \mathrm{nM}\left[4,5-^{3} \mathrm{H}\right.$ leucine (specific activity $60 \mu \mathrm{Ci}$ $\mathrm{nmol}^{-1}$ ) along with $10 \mathrm{n} M$ of nonradioactive leucine to $10 \mathrm{ml}$ samples (11 $\mathrm{nM}$ total final concentration added). After incubation the hot TCA insoluble fraction was then collected on filters. In addition, analogous to the isotope dilution experiments with $\left[{ }^{3} \mathrm{H}\right]$ thymidine, various amounts of nonradioactive leucine (5 to $50 \mathrm{nM}$ ) were added to subsamples and the maximum incorporation rate was calculated (Kirchman et al. 1986).

Since the Delaware Estuary is well mixed (Sharp et al. 1986), areal bacterial production ( $\mathrm{mg} \mathrm{C} \mathrm{m}{ }^{-2} \mathrm{~d}^{-1}$ ) was estimated by multiplying the hourly volumetric rates ( $\mu \mathrm{g} \mathrm{Cl}^{-1} \mathrm{~h}^{-1}$ ) by the water column depth and 24. To convert to estimates of production, the thymidine and leucine incorporation rates were multiplied by the average conversion factors determined during this study (see 'Results'). Cell production was converted to biomass production by assuming $20 \mathrm{fg} \mathrm{C} \mathrm{Cell}^{-1}$ (Lee \& Fuhrman 1987). Since thymidine and leucine gave very similar results, the average of the 2 was used for comparisons with primary production rates.

Conversion factor experiments. The factor for converting $\left[{ }^{3} \mathrm{H}\right]$ thymidine and $\left[{ }^{3} \mathrm{H}\right]$ leucine incorporation rates to rates of bacterial cell production was estimated by the method of Kirchman et al. (1982). In July an untreated water sample was diluted 10 -fold with filtersterilized water from the same sampling site. For the other months, water was filtered through a $1.0 \mu \mathrm{m}$ 
Nuclepore filter and diluted 1:1 with filter-sterilized water. The fact that bacterial abundance increased exponentially (see 'Results') suggests, although does not prove, that grazing on bacteria was minimized. Duplicate subsamples were removed at various times to determine rates of $\left[{ }^{3} \mathrm{H}\right]$ thymidine and $\left[{ }^{3} \mathrm{H}\right]$ leucine incorporation and bacterial abundance, using the methods described above.

Conversion factors were calculated by 2 algorithms. The first was that originally described by Kirchman et al. (1982) as modified by Bell et al. (1983). The final equation is

$$
C=\frac{\mu N(t)}{v(t)}
$$

where $N(t)$ and $v(t)=$ respectively, the bacterial abundance and incorporation rate at any time $t ; \mu=$ the slope of $\ln (N(t))$ versus time, i.e. the growth rate. This algorithm will be referred to as the derivative method.

The second algorithm was outlined by Riemann et al. (1987). The conversion factor is the number of bacterial cells produced over a selected time period of the experiment (essentially, the final bacterial abundance minus the initial bacterial abundance for that time period) divided by the total amount of radiolabel incorporated during that selected time period. The total amount was measured by integrating the incorporation rates over the experimental time. This algorithm will be referred to as the integrative method.

The error of the integrative conversion factor was calculated with propagation of error equations (Bevington 1969), based on $15 \%$ errors associated with measuring incorporation and bacterial abundance. The error of the derivative conversion factor was based on the measured standard deviation of conversion factors during the experiment.

\section{RESULTS}

Incorporation of a single $5 \mathrm{nM}\left[{ }^{3} \mathrm{H}\right]$ thymidine addition into the cold TCA insoluble fraction was measured at stations positioned approximately every $10 \mathrm{~km}$ along the Delaware Estuary. Incorporation of a single $11 \mathrm{nM}$ $\left[{ }^{3} \mathrm{H}\right]$ leucine addition into the hot TCA insoluble fraction was also measured. In order to calculate bacterial production from these incorporation rates, conversion factors must be estimated.

\section{Conversion factors}

Factors for converting thymidine and leucine incorporation rates to bacterial production rates (conversion factors) were estimated in samples manipulated to
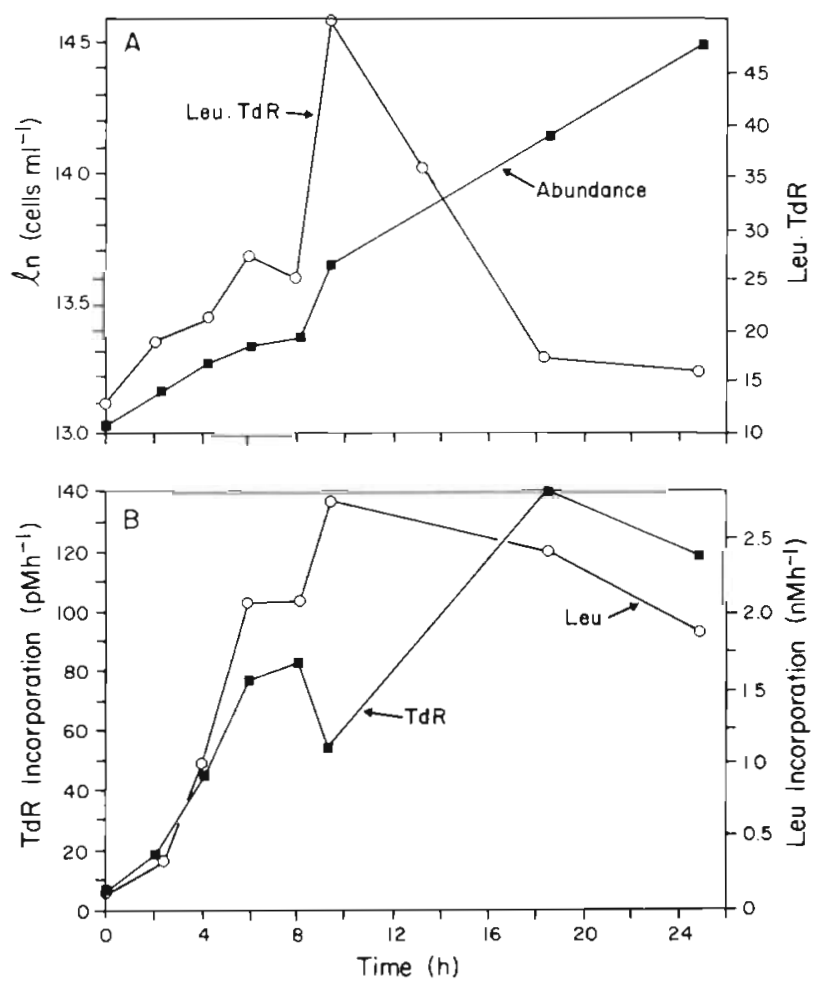

Fig. 1. Growth experiment in July 1986 to estimate conversion factors for the thymidine (TdR) and leucine (Leu) methods. (A) Bacterial abundance and ratio of $\mathrm{TdR}$ to Leu incorporation. (B) Incorporation rates of $\left[{ }^{3} \mathrm{H}\right]$ thymidine and $\left[{ }^{3} \mathrm{H}\right]$ leucine

obtain measurable changes in bacterial abundance and incorporation rates. When bacterial grazing was minimized by filtration and dilution with filteredsterilized water, bacterial abundance increased exponentially as indicated by the straight line on graphs of ln (bacterial abundance) vs time (Fig. 1A). The exponential model was adequate and accounted for 80 to $99 \%\left(r^{2}\right)$ of the variance in bacterial abundance over time (Table 1 ). Rates of both thymidine and leucine incorporation also increased as the bacteria grew (Fig. 1B). In 3 of 4 experiments, incorporation rates increased more so than did bacterial abundance during the first half of the experiments. That is, incorporation rates per cell initially increased over time (Fig. 2A).

During the initial phase of the growth experiments, calculated conversion factors (derivative method) were high for both thymidine and leucine and then decreased as the bacteria continued to grow (Fig. 2B). Conversion factors decreased within $2 \mathrm{~h}$, the first time point of the experiment (Fig. 2B). In July conversion factors for thymidine decreased from 4.9 to $0.5 \times 10^{18}$ cell $\mathrm{mol}^{-1}$; conversion factors for leucine decreased from 37.5 to $2.5 \times 10^{16} \mathrm{cell} \mathrm{mol}^{-1}$ (Fig. 2B). Conversion factors decreased over time when the factors were calculated by either the derivative method (Fig. 2B) or 
Table 1. Summary of conversion factor experiments in the Delaware Estuary

\begin{tabular}{|c|c|c|c|c|c|c|}
\hline \multirow[t]{3}{*}{ Date } & \multirow{3}{*}{$\begin{array}{l}\text { Growth rate } \\
\qquad\left(\mathrm{h}^{-1}\right)\end{array}$} & \multirow[t]{3}{*}{$r^{2}$} & \multicolumn{4}{|c|}{ Conversion factors ${ }^{b}$} \\
\hline & & & \multicolumn{2}{|c|}{$\operatorname{TdR}\left(10^{18}\right.$ cells $\left.\mathrm{mol}^{-1}\right)$} & \multicolumn{2}{|c|}{ Leu $\left(10^{16}\right.$ cells mol $\left.{ }^{-1}\right)$} \\
\hline & & & $\Sigma$ & Slope & $\Sigma$ & Slope \\
\hline $10 \mathrm{Jul} 1986$ & $0.060(0.0028)$ & 0.99 & $0.70(0.17)$ & $0.71(0.11)$ & $3.1(0.8)$ & $3.6(1.5)$ \\
\hline 29 Apr 1987 & $0.036(0.0037)$ & 0.94 & $1.11(0.26)$ & $0.96(0.07)$ & $7.8(1.8)$ & $7.0(0.6)$ \\
\hline \multicolumn{7}{|l|}{27 May 1987} \\
\hline Control & $0.017(0.0028)$ & 0.86 & $0.80(0.19)$ & $0.78(0.17)$ & $5.6(1.3)$ & $6.5(2.0)$ \\
\hline$+\mathrm{NH}_{4}^{+c}$ & $0.022(0.0016)$ & 0.97 & $0.83(0.190)$ & $0.88(0.14)$ & $5.9(1.4)$ & $5.8(0.91)$ \\
\hline \multicolumn{7}{|l|}{25 Jun 1987} \\
\hline Control & $0.025(0.0042)$ & 0.86 & $1.59(0.37)$ & $1.53(0.31)$ & $6.7(1.6)$ & $7.4(1.3)$ \\
\hline+ Glucose $^{d}$ & $0.020(0.0041)$ & 0.80 & $0.60(0.14)$ & $0.68(0.09)$ & $3.4(0.8)$ & $3.6(0.61)$ \\
\hline \multirow{2}{*}{$\begin{array}{l}+ \text { Glucose } \\
+\mathrm{NH}_{4}^{+d}\end{array}$} & $0.023(0.0024)$ & 0.94 & $0.84(0.19)$ & $0.84(0.12)$ & $4.3(1.0)$ & $3.7(0.73)$ \\
\hline & & $\begin{array}{l}\text { Mean }^{e} \\
\text { (SD) }\end{array}$ & $\begin{array}{c}1.05 \\
(0.40)\end{array}$ & $\begin{array}{c}0.99 \\
(0.37)\end{array}$ & $\begin{array}{l}5.80 \\
(2.01)\end{array}$ & $\begin{array}{c}6.12 \\
(1.72)\end{array}$ \\
\hline \multicolumn{7}{|c|}{ 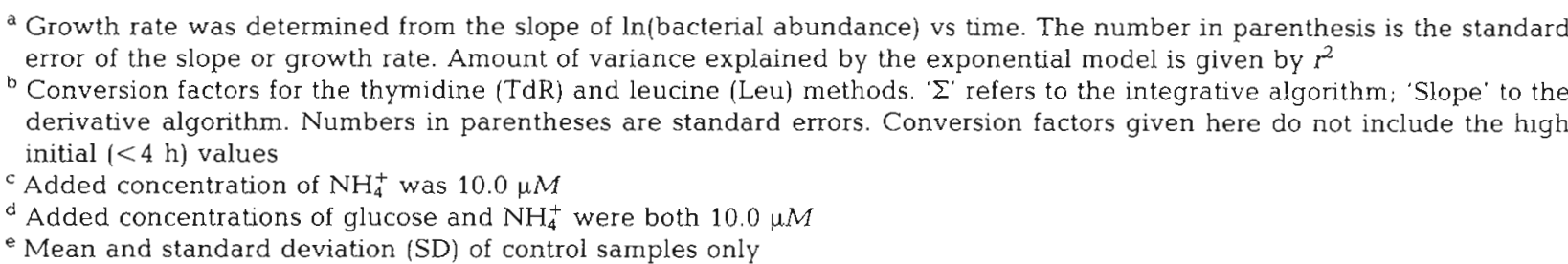 } \\
\hline
\end{tabular}
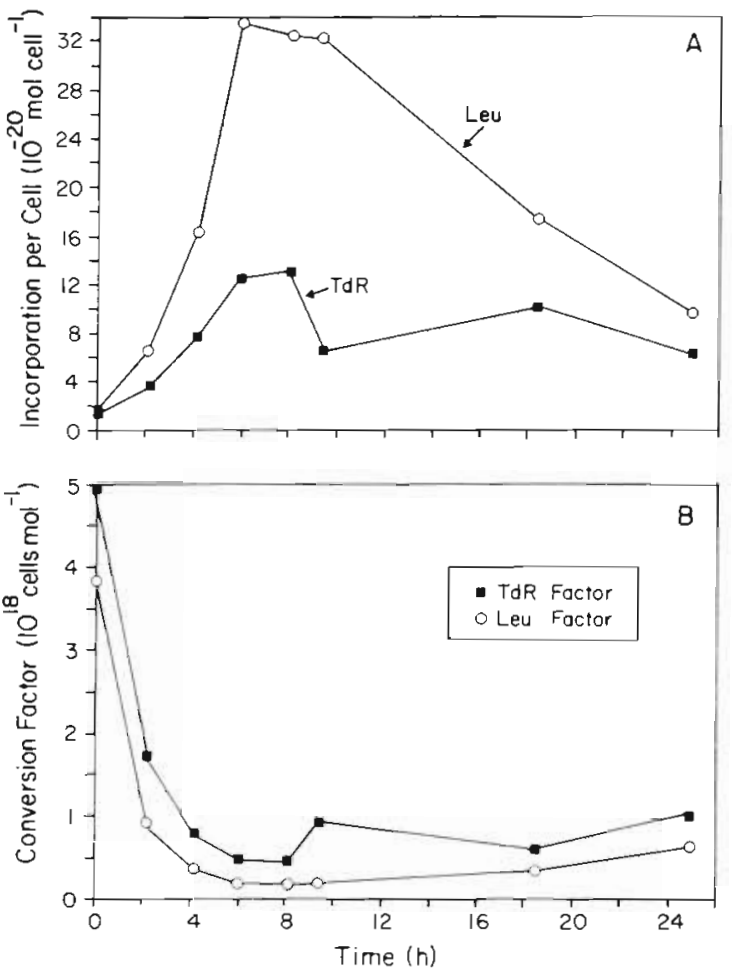

Fig. 2. Growth experiment in July 1986 (see Fig. 1) to estimate conversion factors. (A) Incorporation rates per cell; correct units for leucine are $10^{-19} \mathrm{~mol} \mathrm{cell}^{-1}$ (B) Conversion factors for the thymidine ( $T d R$ ) and leucine (Leu) methods as calculated by derivative algorithm; correct units for leucine are $10^{16} \mathrm{cells}$ $\mathrm{mol}^{-1}$ the integrative method (Fig. 3). The low conversion factors after 4 h were associated with high incorporation rates per cell. This pattern was observed for both thymidine and leucine in May, June and July, and also for leucine in April (e.g. Fig. 2 and leucine data in Fig. 4). In April thymidine incorporation rates per cell were relatively constant (Fig. 4A) and likewise the conversion factor fluctuated around $1 \times 10^{18}$ cell mol $^{-1}$ (Fig. $4 B$ ). Except for the large initial values, conversion factors were relatively constant (Figs. 2 and 3 ).,

For both thymidine and leucine, the derivative and integrative methods gave the same conversion factors. The thymidine conversion factors varied from $0.7 \times$

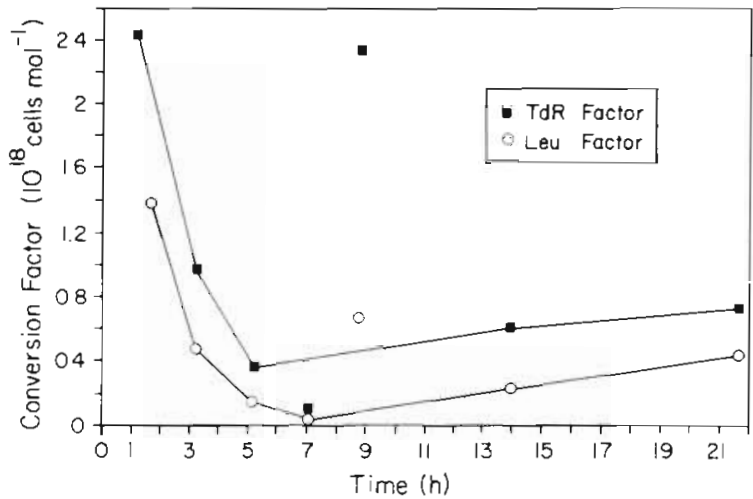

Fig. 3. Conversion factors for thymidine (TdR) and leucine (Leu) methods as calculated by the integrative algorithm (April 1987). Correct units for leucine are $10^{16}$ cells mol ${ }^{-1}$ Lines drawn by eye 

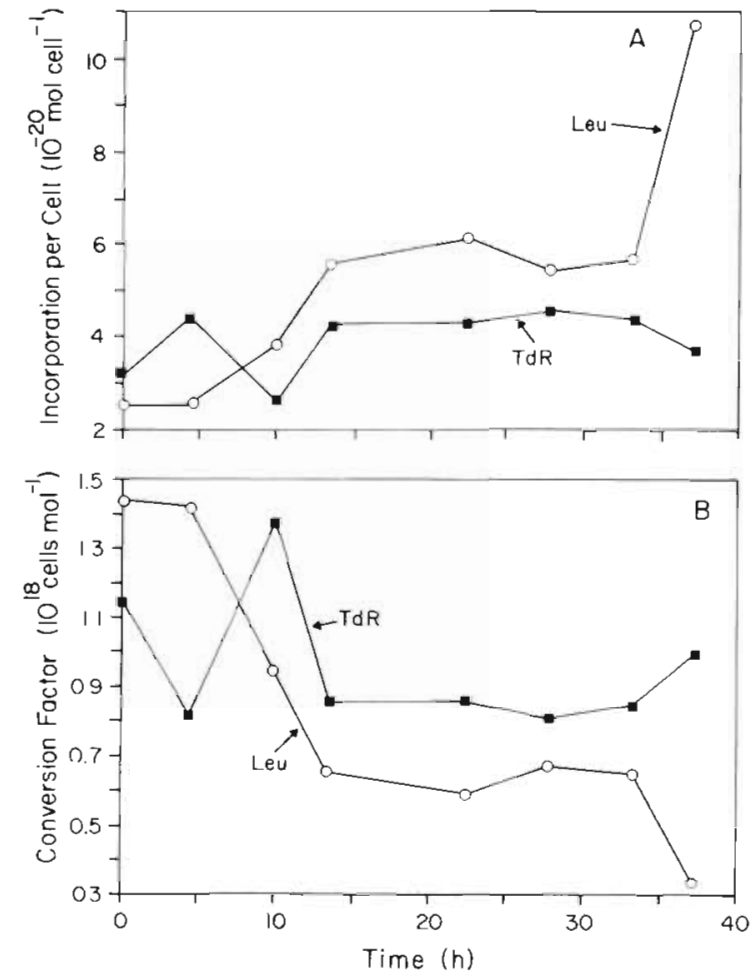

Fig. 4. Growth experiment in April 1987 to estimate conversion factors. (A) Incorporation rates per cell; correct units for leucine are $10^{-19} \mathrm{~mol} \mathrm{cell}{ }^{-1}$. (B) Conversion factors for the thymidine (TdR) and leucine (Leu) methods as calculated by the derivative algorithm; correct units for leucine are $10^{16}$ cells $\mathrm{mol}^{-1}$

$10^{18}$ cells mol ${ }^{-1}$ to $1.6 \times 10^{18}$ cells $\mathrm{mol}^{-1}$ (Table 1 ). The factors for leucine varied from $3.1 \times 10^{16}$ cells mol $^{-1}$ to $7.8 \times 10^{16}$ cells $\mathrm{mol}^{-1}$.

Addition of ammonium, glucose, or ammonium plus glucose had no significant effect on growth rates (Table 1). Addition of glucose lowered the thymidine conversion factor from $1.59 \pm 0.37 \times 10^{18}$ cells mol $^{-1}$ to $0.60 \pm$ $0.14 \times 10^{18}$ cells $\mathrm{mol}^{-1}$ and the leucine conversion factor from $6.7 \pm 1.6 \times 10^{16}$ cells mol ${ }^{-1}$ to $3.4 \pm 0.8 \times$ $10^{16}$ cells $\mathrm{mol}^{-1}$. Addition of ammonium alone had no significant effect on conversion factors (Table 1), and conversion factors in experiments with both ammonium and glucose added did not differ from factors measured in experiments with glucose added alone (Table 1). The significant reduction in conversion factors by glucose additions but not by ammonium additions was observed for both the derivative and integrative algorithms (Table 1).

\section{Incorporation into protein and isotope dilution}

The average conversion factor for thymidine measured in the Delaware Estuary $\left(1 \times 10^{18} \mathrm{cell} \mathrm{mol}^{-1}\right)$ is low compared with the theoretical factor $\left(2.0 \times 10^{18}\right.$ cell $\mathrm{mol}^{-1}$ ) of Fuhrman \& Azam (1982). At least 2 explanations are possible: (1) large amounts of thymidine are actually incorporated into protein, unlike that observed by Fuhrman \& Azam (1982); (2) isotope dilution of the added $\left[{ }^{3} \mathrm{H}\right]$ thymidine is less in the Delaware Bay than estimated by Fuhrman \& Azam (1982) for coastal waters off Southern California. These 2 possibilities were tested.

A substantial amount of $\left[{ }^{3} \mathrm{H}\right]$ thymidine was incorporated into bacterial protein (Table 2). The percentage

Table 2. Incorporation of $\left[{ }^{3} \mathrm{H}\right]$ thymidine into protein in the Delaware Estuary

\begin{tabular}{|c|c|c|c|}
\hline Date & $\begin{array}{c}\text { Distance } \\
\text { upstream } \\
(\mathrm{km})\end{array}$ & $\begin{array}{c}\text { Incorporation } \\
\text { rate }^{\mathrm{a}} \\
\left(\mathrm{p} M \mathrm{~h}^{-1}\right)\end{array}$ & $\%$ Protein \\
\hline 31 Oct 1986 & $\begin{array}{r}110 \\
83 \\
38 \\
-10\end{array}$ & $\begin{array}{r}10.7 \\
6.0 \\
6.7 \\
4.3\end{array}$ & $\begin{array}{l}74 \\
54 \\
61 \\
66\end{array}$ \\
\hline 18 Feb 1987 & $\begin{array}{r}100 \\
56 \\
-4\end{array}$ & $\begin{array}{l}5.8 \\
3.4 \\
6.6\end{array}$ & $\begin{array}{l}100 \\
100 \\
100\end{array}$ \\
\hline 6 Nov 1987 & 83 & 11.5 & 30 \\
\hline 1 Dec 1987 & $\begin{array}{r}102 \\
93 \\
75 \\
65 \\
56 \\
47 \\
10\end{array}$ & $\begin{array}{r}17.8 \\
8.5 \\
7.3 \\
6.4 \\
6.4 \\
3.1 \\
6.5\end{array}$ & $\begin{array}{r}57 \\
98 \\
51 \\
65 \\
47 \\
100 \\
48\end{array}$ \\
\hline
\end{tabular}

varied from $30 \%$ in November to $100 \%$ in February and for one station in December. There was no obvious relationship between this percentage and incorporation rate, location in the estuary, nor time of sampling (Table 2). The high amount of $\left[{ }^{3} \mathrm{H}\right]$ thymidine incorporation into protein in part explains why the conversion factor is relatively low, especially in winter.

The added concentration of $\left[{ }^{3} \mathrm{H}\right]$ thymidine appears to have been adequate for at least the 2 dates examined (Table 3). The maximum incorporation rates $\left(I_{\max }\right)$ measured with isotope dilution experiments were not significantly higher than the rate determined by the $5 \mathrm{n} M$ addition; in fact, the $5 \mathrm{n} M$ rate was higher than $I_{\max }$ in 3 out of 6 cases (Table 3). At least within the limits of the Moriarty \& Pollard (1981) approach, isotope dilution does not appear to have influenced the thymidine conversion factor.

At 4 out of 5 stations tested, $I_{\max }$ of leucine incorpora- 
Table 3. $\left[{ }^{3} \mathrm{H}\right]$ thymidine incorporation rates measured trom the standard 5 n $M$ addition compared with the isotope dilution approach

\begin{tabular}{|c|c|c|c|c|}
\hline \multirow[t]{2}{*}{ Date } & \multirow[t]{2}{*}{ Distance upstream $(\mathrm{km})$} & \multicolumn{3}{|c|}{ Incorporation rates $\left(\mathrm{p} M \mathrm{~h}^{-1}\right)$} \\
\hline & & $I_{\max }{ }^{\mathrm{d}}$ & $5 n M$ & $5 \mathrm{nM} / I_{\max }{ }^{b}$ \\
\hline \multirow[t]{5}{*}{31 Oct 1986} & 110 & $9.3 \pm 1.9^{\mathrm{c}}$ & 10.7 & 1.1 \\
\hline & 83 & $1.8 \pm 0.17$ & 5.1 & 2.8 \\
\hline & 47 & $4.8 \pm 0.81$ & 4.5 & 0.9 \\
\hline & 19 & $1.2 \pm 0.01$ & 4.8 & 4.0 \\
\hline & -2 & $1.03 \pm 0.12$ & 6.0 & 5.8 \\
\hline 18 Feb 1987 & 90 & $8.7 \pm 0.14$ & 8.7 & 1.0 \\
\hline \multicolumn{5}{|c|}{$\begin{array}{l}I_{\text {max }} \text { is the maximum incorporation rate determined by the isotope dilution approach (Moriarty \& Pollard } 1981 \text {, Kirchman et al. } \\
1986 \text { ) }\end{array}$} \\
\hline \multicolumn{5}{|c|}{ Ratio of the $5 \mathrm{n} M$ rate to the maximum incorporation rate } \\
\hline${ }^{c}$ Rates \pm standa & & & & \\
\hline
\end{tabular}

tion was higher than the rate determined from the single $11 \mathrm{nM}$ addition (Table 4). The ratio of the $11 \mathrm{nM}$ rate to $I_{\max }$ ranged from 0.7 to 1.1 (Table 4 ).

\section{Bacterial production}

Using conversion factors measured in April, bacterial production was calculated from thymidine and leucine incorporation rates measured in April when phytoplankton biomass (chlorophyll) reaches its seasonal maximum (Pennock \& Sharp 1986). Chlorophyll concentrations peaked at $40 \mu \mathrm{g} \mathrm{l^{-1 }} 30$ to $80 \mathrm{~km}$ upstream from the mouth of the Delaware Estuary (Fig. 5A). There was a sharp maximum of phytoplankton production (Fig. 5B for volumetric rates; Fig. 6A for areal rates) at $50 \mathrm{~km}$, but primary amine concentrations were highest at $90 \mathrm{~km}$ and decreased downstream (Fig. 5B). The

Table 4. $\left[{ }^{3} \mathrm{H}\right]$ leucine incorporation rates measured from a single $11 \mathrm{n} M$ addition compared with the isotope dilution approach on 31 Oct 1986

\begin{tabular}{|c|c|c|c|}
\hline \multirow{2}{*}{$\begin{array}{l}\text { Distance } \\
\text { upstream } \\
(\mathrm{km})\end{array}$} & \multicolumn{3}{|c|}{ Incorporation rates $\left(\mathrm{p} M \mathrm{~h}^{-1}\right)$} \\
\hline & $I_{\max }{ }^{a}$ & $11 \mathrm{n} M$ & $11 \mathrm{nM} / I_{\max }{ }^{b}$ \\
\hline 110 & $230 \pm 26^{c}$ & 256 & 1.1 \\
\hline 83 & $174 \pm 2.7$ & 137 & 0.79 \\
\hline 47 & $175 \pm 13$ & 119 & 0.68 \\
\hline 19 & $150 \pm 1.4$ & 130 & 0.87 \\
\hline-2 & $164 \pm 3$ & 136 & 0.83 \\
\hline \multicolumn{4}{|c|}{$\begin{array}{l}{ }^{2} I_{\text {max }} \text { is the maximum incorporation rate determined by the } \\
\text { isotope dilution approach (Moriarty \& Pollard } 1981 \text {, } \\
\text { Kirchman et al. 1986) } \\
\text { b Ratio of the } 11 \mathrm{nM} \text { rate to the maximum incorporation } \\
\text { rate } \\
{ }^{c} \text { Rates } \pm \text { standard error }\end{array}$} \\
\hline
\end{tabular}

decrease in chlorophyll concentrations around $80 \mathrm{~km}$ is caused by turbidity-induced light-limitation of the phytoplankton (Pennock 1985). Bacterial abundances were highest $\left(3.5 \times 10^{9}\right.$ cells $\left.1^{-1}\right)$ in waters with high chlorophyll concentrations; abundance decreased slightly in the turbidity maximum of the estuary (Fig. 5C).

Bacterial production based on thymidine incorporation was highest at $50 \mathrm{~km}$ whereas leucine-based production estimates were highest at $40 \mathrm{~km}$ (Fig. 5D). Both measures indicated that bacterial production decreased upstream along with phytoplankton production, even though chlorophyll and primary amine concentrations remained high (Fig. 5B). Thus, except for the offset at 40 to $50 \mathrm{~km}$, thymidine and leucine incorporation covaried over the entire survey of the Delaware. Overall, bacterial production varied from 10 to $80 \times 10^{6}$ cells $^{-1} \mathrm{~h}^{-1}$ during April (Fig. 5D).

The spatial variation in both primary and bacterial production is qualitatively the same whether the rates are expressed per volume (Fig. 5) or integrated over depth (areal rates; Fig. 6A). However, the quantitative comparison between phytoplankton and bacterial production is quite different depending on how the rates are expressed. Bacterial production is a constant $4 \%$ of maximum phytoplankton ${ }^{14} \mathrm{CO}_{2}$ fixation when volumetric rates are used (Fig. 6B), but varies from 25 to over $100 \%$ when areal rates are used (integrated over the entire water column). The difference is because light attenuation in the estuary is high, especially at the turbidity maximum (Pennock \& Sharp 1986), which inhibits primary production but not bacterial production, at least directly. Light indirectly affects bacterial production through its effect on primary production. but this does not change the calculation of areal rates. Volumetric rates of ${ }^{14} \mathrm{CO}_{2}$ fixation are those for optimal light conditions (Pennock \& Sharp 1986). Integrating the volumetric rates to obtain areal rates reduces pri- 
mary production relative to bacterial production, because of light limitation of phytoplankton growth (Pennock \& Sharp 1986).
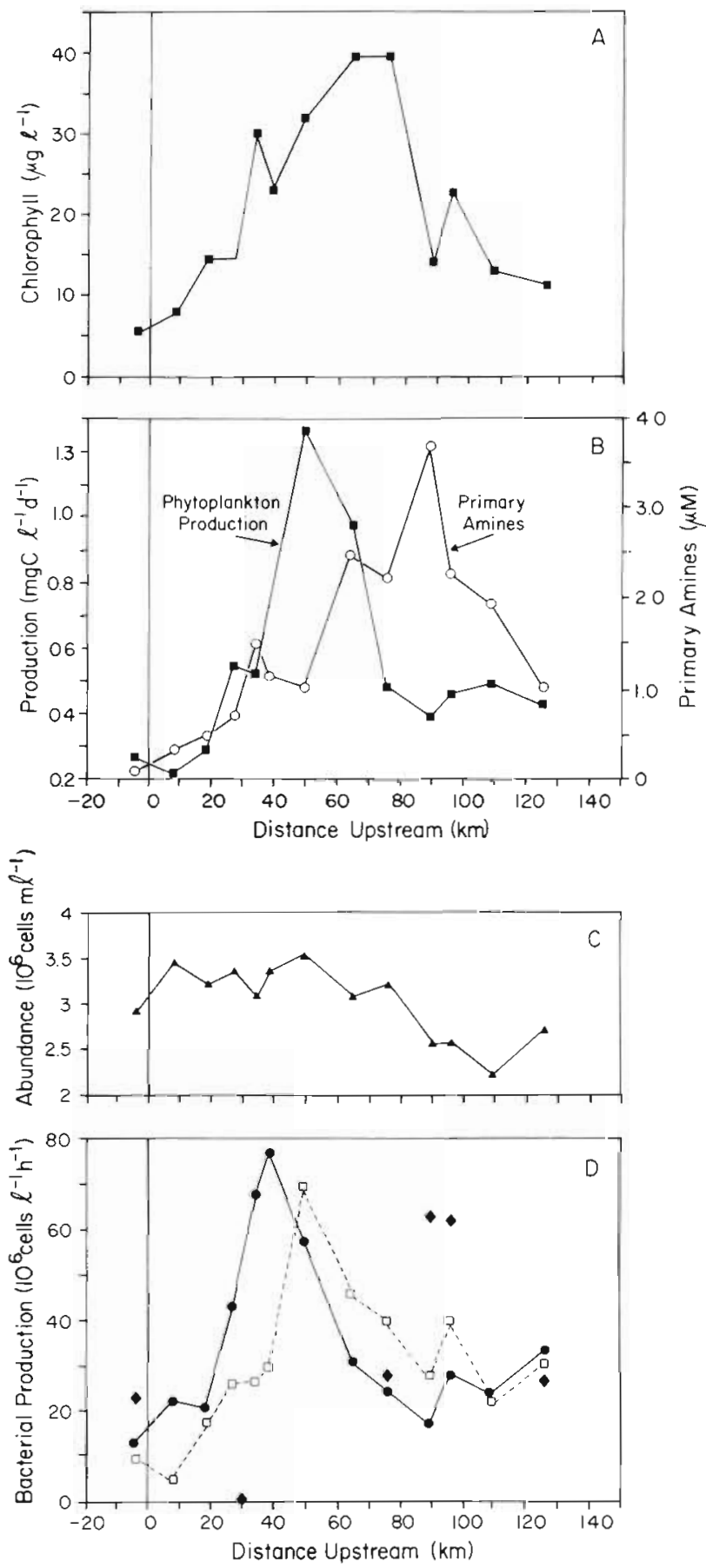

Fig. 5. Phytoplankton and bacteria in the Delaware Estuary in April 1987. (A) Chlorophyll a. (B) Phytoplankton production under optimal light conditions and primary amine concentrations (OPA-reactive material). (C) Bacterial abundance. (D) Bacterial production calculated from thymidine incorporation rates $(\square)$, leucine incorporation rates $(\bullet)$, and taken from Coffin \& Sharp (1987) (๑) measured in April 1985
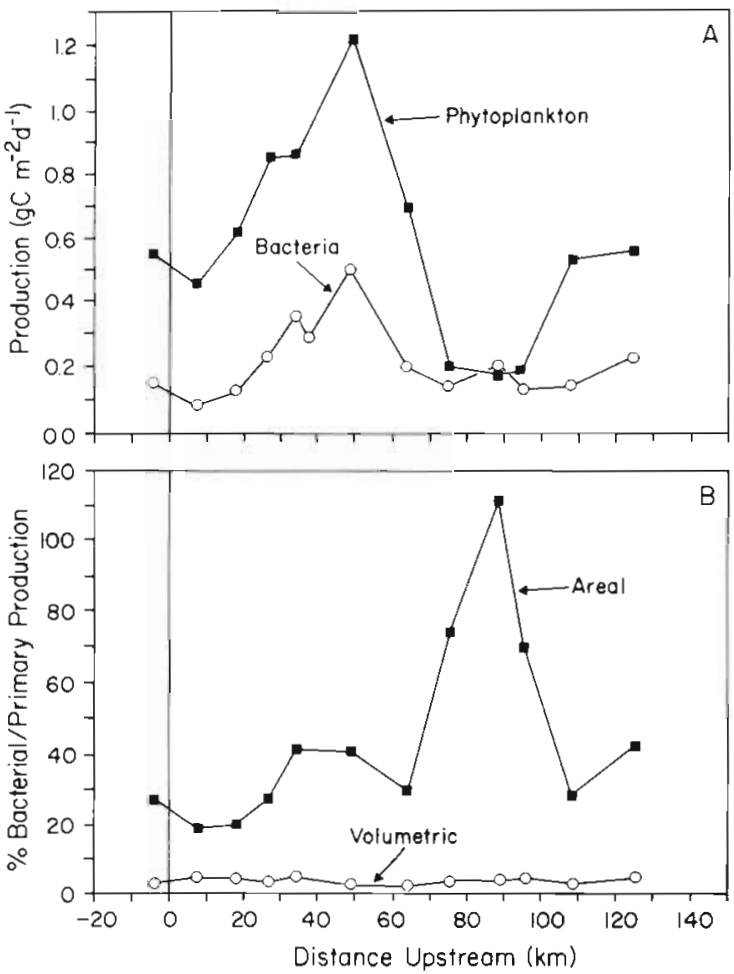

Fig. 6. (A) Areal rates of primary production and bacterial production in April 1987. (B) Ratio of bacterial production to primary production, for volumetric $\left(\mu \mathrm{g} \mathrm{C} \mathrm{l}^{-1} \mathrm{~d}^{-1}\right)$ and areal ( $\mathrm{mg} \mathrm{C} \mathrm{m} \mathrm{m}^{-2} \mathrm{~d}^{-1}$ ) rates. Volumetric rates of primary production were determined under optimal light conditions whereas calculations of areal rates reflects light limitation of primary production but not bacterial production. See Fig. 5 for more data

\section{DISCUSSION}

Estuaries like the Delaware Bay provide challenging environments in which to examine the factors that control bacterial biomass levels and growth rates. Physico-chemical parameters that directly or indirectly affect bacterial production change greatly over relatively short distances. In the Delaware Bay, for example, phytoplankton biomass and production can vary at least 2 -fold within tens of kilometers. In response, bacterial production varies as well, although, not surprisingly, bacterial abundance is more constant. These large changes allow the investigator to examine a great range in environmental and bacterial parameters among regions that are separated by a few kilometers. However, the great variety of growth environments potentially causes methodological problems, especially in attempting to measure bacterial production.

The high incorporation of $\left[{ }^{3} \mathrm{H}\right]$ thymidine into protein is one such methodological problem (Ducklow et al. 1985, McDonough et al. 1986, Robarts et al. 1986, Hollibaugh 1988). Basing production rates on only 
radioactivity in DNA does not necessarily solve the problem, even if the DNA isolation procedure is assumed to be without errors. When $>50 \%$ of assimilated $\left[{ }^{3} \mathrm{H}\right]$ thymidine is incorporated into protein, the remaining incorporation of ${ }^{3} \mathrm{H}$-radioactivity into DNA may not accurately reflect total DNA synthesis of all cells in bacterial assemblages. The February experiment discussed here is an extreme example. No $\left[{ }^{3} \mathrm{H}\right]$ thymidine incorporation into DNA was measurable, yet Coffin \& Sharp (1987) observed bacterial growth and grazing on bacteria during February 1985, indicating that bacterial DNA synthesis was probably occurring during our experiments.

One solution to the uncertainty in interpreting thymidine incorporation rates is to use the empirical approach suggested by Kirchman et al. (1982). With this approach, the precise relationship of $\left[{ }^{3} \mathrm{H}\right]$ thymidine incorporation to DNA synthesis is unimportant as long as the relationship of incorporation to bacterial production is known, i.e. the empirical conversion factor. The empirical factors are valid, by definition, even if $100 \%$ of thymidine incorporation is into protein. Riemann et al. (1987) argued that the conversion factor for thymidine was a constant $1.1 \times 10^{18} \mathrm{cell} \mathrm{mol}^{-1}$. We measured a very similar factor, but we also found that addition of glucose could reduce the conversion factor, suggesting that it is not constant but in some cases dependent on the concentration of organic compounds.

The integrative and the derivative algorithms for calculating conversion factors gave similar results in this study (see also Scavia \& Laird 1987). It can be shown mathematically that the 2 algorithms have to agree when bacterial growth is balanced. However, nonexponential changes in bacterial abundance (in particular, lags in bacterial growth) cause problems for both algorithms. The integrative algorithm is the better method when lags occur. Presumably, macromolecular precursors like thymidine and leucine are incorporated during lag phases because macromolecular synthesis is preceding and is necessary for subsequent increases in cell numbers. The integrative method would be able to account for this unbalanced growth phase. In contrast, the derivative method should only be applied when changes in bacterial abundance can be explained by an exponential model (Kirchman et al. 1982). For this limited case, the derivative method is superior because it uses all the data on bacterial abundance, not just 2 endpoints. When the exponential model is justified, conversion factors calculated by the derivative method will have more degrees of freedom and smaller experimental errors than the integrative approach (Table 1 ).

Kirchman et al. (1982) originally used incorporation rates from the time-zero sample to calculate conversion factors, but here we show that these initial incorporation rates give very high conversion factors which are undoubtedly inappropriate to use for ecological studies. Other investigators have also noted that changes in incorporation rates and bacterial abundance are sometimes not coupled, resulting in high conversion factors (e.g. Ducklow \& Hill 1985), but this issue has not been resolved. The variation of conversion factors within an experiment has been mentioned, although not discussed thoroughly (e.g. Newell et al. 1987). The choice of algorithm is not the problem as both the integrative and derivative methods gave similar results in our experiments.

We suggest that extra- and intracellular isotope dilution is the most likely cause for the high initial conversion factors. Other possible changes, e.g. in nonspecific incorporation or DNA content per cell, are too slow or small to account for the $>10$-fold variation observed over a few hours in our experiments. The initial dilution is probably caused directly (extracellular dilution) or indirectly (intracellular dilution) by dissolved compounds artifactually released during setting up of the experiment. Filtration, which is a necessary step during growth experiment preparations, can increase dissolved amino acid concentrations and probably other compounds (like thymidine) as well (Fuhrman \& Bell 1985). Elevated concentrations would initially cause extracellular isotope dilution and probably increase intracellular dilution as well. As bacteria assimilate the dissolved compounds, concentrations and isotope dilution decrease. Concentrations of primary amines decrease over time in conversion factor experiments (data not presented). At least based on the Moriarty \& Pollard (1981) approach, Kirchman et al. (1986) found that isotope dilution of leucine decreases over time in conversion factor experiments. If we assume isotope dilution is the main problem, then the high initial thymidine conversion factors are not ecologically relevant, since isotope dilution of added $\left[{ }^{3} \mathrm{H}\right]$ thymidine was not measurable (at least by the Moriarty \& Pollard [1981] approach) in untreated samples.

The same mechanism would explain the high initial conversion factors for leucine, although isotope dilution was measurable in untreated samples from the Delaware. Free extracellular leucine alone may be responsible for the greatest isotope dilution (1.5-fold) measured in untreated samples. Since the added leucine was $11 \mathrm{n} M$, isotope dilution by an in situ leucine concentration of $10 \mathrm{n} M$ (Coffin in press) would cause rates to be underestimated by $(11 \mathrm{n} M+10 \mathrm{nM}) / 11 \mathrm{n} M$ or about 1.5. However, 1.5-fold isotope dilution would not account for the very high conversion factors measured in the initial stages of the growth experiments; the initial factors were as much as 10 -fold higher than those measured at the end of the experiment. These high initial conversion factors are probably caused by isotope dilution. Thus, the lower conversion factors are 
more reasonable to use for estimating bacterial production.

If the initial $(<4 \mathrm{~h})$ high conversion factors are not used, then conversion factors measured in experiments $>4 \mathrm{~h}$ and sometimes approaching $10 \mathrm{~h}$ with samples from Delaware Bay have to be used. In other environments where bacterial growth rates are slower, even longer experiments may be necessary. Some investigators would discard any result from such long experiments because of 'bottle effects' (e.g. Ferguson et al. 1984). However, these experiments are still shorter than the average generation time of the bacterial assemblage, the shortest being about $10 \mathrm{~h}$ in Delaware Bay (calculated from Table 1). Thus, changes in species composition and thymine content per DNA cannot be large. It must be remembered that the success of the conversion factor experiment depends on reproducing, not necessarily the growth rate, but the relationship between incorporation rates and bacterial production found in situ.

Even if the conversion factor experiments were problem-free, they are too time-consuming and labor-intensive to examine how bacterial production varies over short time and space scales. The danger in measuring thymidine incorporation without doing conversion factor experiments is that the observed variation in thymidine incorporation could be due to changes in conversion factors rather than bacterial production. However, if an independent measure of production covaried with thymidine incorporation, then it is highly unlikely that the observed variation in incorporation rates is due to changing conversion factors. For this reason we have been measuring both leucine and thymidine incorporation in the Delaware Estuary. During many months in the estuary, on the scale of $10 \mathrm{~km}$, leucine and thymidine covary and give the same qualitative picture of how bacterial production varies in the estuary (e.g. Fig. 5C). This covariance exists in spite of the methodological problems associated with each method. Although the 2 methods share some analogous theoretical features (Kirchman et al. 1986), thymidine and leucine incorporation are measured independently and the metabolic fate of these compounds is distinct. The fact that both give the same pattern increases our confidence about how bacterial production varies in the Delaware Estuary.

Coffin \& Sharp (1987) measured bacterial production in the Delaware by the cycloheximide (grazer inhibition) method for April 1985 as well as other months. Their estimates of bacterial production were remarkably similar to those reported here for April 1987 (Fig. 5D). The largest difference was at $90 \mathrm{~km}$ upstream where their values were about twice that of the thymidine and leucine estimates. Interannual variability may account for this difference. However, they were unable to measure any production at $30 \mathrm{~km}$ where both the thymidine and leucine methods indicate that production in 1987 was $35 \times 10^{6}$ cells $\mathrm{l}^{-1} \mathrm{~h}^{-1}$ (Fig. 5D).

The data of Coffin \& Sharp (1987), this study, and other thymidine and leucine measurements (Kirchman et al. unpubl.) all indicate the importance of phytoplankton production in determining the variation in bacterial production in the Delaware Estuary. The close coupling between bacteria and phytoplankton in the Delaware is noteworthy because it exists in spite of the high anthropogenic input of organic matter at about $130 \mathrm{~km}$ upstream near the Philadelphia metropolitan area (Sharp et al. 1982). Perhaps the allochthonous carbon is not readily used by bacteria compared with compounds produced directly or indirectly by phytoplankton. However, some of the allochthonous carbon is used by bacteria, because bacterial production exceeded primary production in the turbidity maximum where areal primary production was low. This was also shown by Coffin \& Sharp (1987).

It is not clear why bacterial production was relatively low $70 \mathrm{~km}$ and further upstream in the estuary, where primary amine concentrations are high. One explanation is that the primary amines (OPA-reactive material) measured in this region of the estuary are not used by bacteria. However, in growth experiments that minimize grazing on bacteria, OPA-reactive material (primary amines) can be reduced to below limits of detection (Kirchman et al. unpubl.). A more likely explanation is that bacterial production is controlled by the flux, not concentration of dissolved organic matter (DOM). Thus, bacterial production would covary with primary production, the largest source of organic matter in the Delaware (Cifuentes 1987), and not merely with DOM concentrations. The control of bacterial production in the Delaware Estuary is currently being examined in further detail.

Acknowledgements. We thank R. Keil and M. Montgomery for technical assistance, and J. Sharp for data on chlorophyll concentrations and primary production and for his critical comments on the manuscript. We also appreciated the critical reviews by H.W. Ducklow, S. Y Newell, and an anonymous reviewer. This research was supported in part by NOAA Sea Grant NA 86AA-D-SG040 and NSF OCE 86-14170.

\section{LITERATURE CITED}

Azam, F., Fenchel, T., Field, J. G., Gray, J. S., Meyer-Reil, L.-A., Thingstad, F. (1983). The ecological role of watercolumn microbes in the sea. Mar. Ecol. Prog. Ser. 10: 257-263

Bell, R. T., Ahlgren, G. M., Ahlgren, I. (1983). Estimating bacterioplankton production by measuring $\left[{ }^{3} \mathrm{H}\right]$ thymidine incorporation in a eutrophic Swedish Lake. Appl. environ. Microbiol. 45: 1709-1721

Bevington, P. R. (1969). Data reduction and error analysis for the physical sciences. McGraw-Hill, New York 
Coffin, R. B. (in press). Bacterial uptake of dissolved free and combined amino acids in estuarine waters. Limnol Oceanogr.

Coffin, R. B., Sharp, J. H. (1987). Microbial trophodynamics in the Delaware Estuary. Mar. Ecol. Prog. Ser. 41: 253-266

Cifuentes, L. A. (1987). Sources and biogeochemistry of organic matter in Delaware Estuary. Ph.D. thesis, University of Delaware

Ducklow, H. W., Hill, S. M., Gardner, W. D. (1985), Bacterial growth and the decomposition of particulate organic carbon collected in sediment traps. Cont. Shelf. Res. 4: $445-464$

Ducklow, H. W. (1983). The production and fate of bacteria in the oceans. Bioscience 33: 494-501

Ferguson, R. L., Buckley, E. N., Palumbo, A. V (1984). Response of marine bacterioplankton to differential filtration and confinement. Appl. environ. Microbiol. 47: 49-55

Fuhrman, J. A., Azam, F. (1982). Thymidine incorporation as a measure of heterotrophic bacterioplankton production in marine surface waters: evaluation and field results. Mar. Biol. 66: 109-120

Fuhrman, J. A., Bell, T. M. (1985). Biological considerations in the measurement of dissolved free amino acids in seawater and implications for chemical and microbiological studies. Mar. Ecol. Prog. Ser. 25: 13-21

Hobbie, J. E., Daley, R. J., Jasper, S. (1977). Use of Nuclepore filters for counting bacteria by fluorescence microscopy. Appl. environ. Microbiol. 33: 1225-1228

Hobbie, J. E., Cole, J. J. (1984). Response of a detrital foodweb to eutrophication. Bull. mar. Sci. 35: 357-363

Hollibaugh, J. T (1988). Limitations of the $\left[{ }^{3} \mathrm{H}\right]$ thymidine method for estimating bacterial productivity due to thymidine metabolism. Mar. Ecol. Prog. Ser. 43: 19-30

Kirchman, D., K'ness, E., Hodson, R. (1985). Leucine incorporation and its potential as a measure of protein synthesis by bacteria in natural aquatic systems. Appl. environ. Microbiol. 49: 599-607

Kirchman, D., Ducklow, H. W., Mitchell, R. (1982). Estimates of bacterial production and growth rates based on changes in biomass and uptake rates. Appl. environ. Microbiol. 44: 1296-1307

Kirchman, D., Newell, S., Hodson, R. (1986). Leucine incorporation versus biosynthesis: implications for measuring rates of protein synthesis and biomass production by bacteria in marine systems. Mar Ecol. Prog. Ser. 32: 47-59
Lee, S., Fuhrman, J. A. (1987). Relationships between biovolume and biomass of naturally derived marine bacterioplankton. Appl. environ. Microbiol 53: 1298-1303

McDonough, R. J., Sanders, R. W., Porter, K. G., Kirchman, D. L. (1986). Depth distribution of bacterial production in a stratified lake with an anoxic hypolimnion. Appl. environ. Microbiol. 52 (5): 992-1000

Moriarty, D. J. W., Pollard, P. C. (1981). DNA synthesis as a measure of bacterial productivity in seagrass sediments. Mar. Ecol. Prog. Ser. 5: 151-156

Newell, S. Y., Fallon, R. D., Sherr, B. F., Sherr, E. B. (1987) Mesoscale temporal variation in bacterial standing crop. percent active cells, productivity and output in a saltmarsh tidal river. Verh. int. Verein. Limnol. 23

Parsons, T R., Maita, Y., Lalli, C. M. (1984). A manual of chemical and biological methods for seawater analysis Pergamon Press, Oxford

Pennock, J. R. (1985). Chlorophyll distributions in the Delaware Estuary: regulation by light-limitation. Estuar coast Shelf Sci. 21: 711-725

Pennock, J. R., Sharp, J. H. (1986). Phytoplankton production in the Delaware Estuary: temporal and spatial variability. Mar. Ecol. Prog. Ser. 34: 143-155

Riemann, B., Bjørnsen, P. K. Newell, S., Fallon, R. (1987). Calculation of cell production of coastal marine bacteria based on measured incorporation of $\left[{ }^{3} \mathrm{H}\right]$ thymidine. Limnol. Oceanogr. 32 (2): 471-476

Robarts, R. D., Wicks, R. J., Sephton, L. M. (1986). Spatial and temporal variations in bacterial macromolecule labeling with [methy] $-{ }^{3} \mathrm{H}$ ] thymidine in a hypertrophic lake. Appl. environ. Microbiol. 52: 1368-1373

Scavia, D., Laird, G. A. (1987). Bacterioplankton in Lake Michigan: dynamics, controls, and significance to carbon flux. Limnol. Oceanogr. 32 (5) : 1017-1033

Sharp, J. H., Culberson, C. H., Church, T. M. (1982). The chemistry of the Delaware Estuary. General considerations. Limnol. Oceanogr. 27: 1015-1028

Sharp, J. H., Cifuentes, L. A., Coffin, R. B., Pennock, J. R. Wong, K.-C. (1986). The influence of river variability on the circulation chemistry and microbiology of the Delaware Estuary. Estuaries 4A: 261-269

Taylor, G. T., Pace, M. L. (1987). Validity of eucaryote inhibitors for assessing production and grazing mortality of marine bacterioplankton. Appl. environ. Microbiol. 53 (1): $119-128$ 